\title{
Pengaruh Komunikasi dan Lingkungan Kerja Terhadap Kinerja Pegawai Pada Dinas Perdagangan Provinsi Sumatera Selatan
}

\author{
Donny Dominggo Saragi ${ }^{1}$, Suhada$^{2}$, Puput Sekar Sari ${ }^{3}$ \\ 1 Fakultas Ekonomi dan Bisnis UPGRI Palembang, donnydominggo@gmail.com \\ 2Fakultas Ekonomi dan Bisnis UPGRI Palembang, suhadaahmadmadjid@gmail.com \\ ${ }^{3}$ Fakultas Ekonomi dan Bisnis UPGRI Palembang, sari puput88@univpgri-palembang.ac.id
}

\begin{abstract}
ABSTRAK
Metode penelitian yang digunakan adalah metode penelitian kuantitatif, dengan populasi seluruh pegawai Kantor Dinas Perdagangan Provinsi Sumatera Selatan berjumlah 69 orang pegawai. Sampel yang digunakan dalam penelitian ini menggunakan teknik sampling jenuh sehingga diperoleh sampel sebanyak 69 pegawai. Teknik pengumpulan data dilakukan dengan observasi dan kuesioner. Teknik analisis data menggunakan analisis regresi linear berganda, koefisien determinasi, pengujian hipotesis uji $t$ dan uji $F$. Hasil penelitian ini dapat diketahui bahwa nilai persamaan regresi linear berganda $Y=16,497+0,443 X_{1}+0,583 X_{2}+e$. Hasil koefisien determinasi menunjukan nilai $R$ Square sebesar 0,508 atau $50,8 \%$ artinya kontribusi sumbangan pengaruh Komunikasi $\left(X_{1}\right)$ dan Lingkungan Kerja $\left(\mathrm{X}_{2}\right)$ terhadap Kinerja Pegawai $(\mathrm{Y})$ sebesar $50,8 \%$. Hasil pengujian hipotesis uji t Komunikasi $\left(\mathrm{X}_{1}\right)$ terhadap Kinerja Pegawai $(\mathrm{Y})$ diperoleh nilai signifikan $0,014<\alpha$ signifikan 0,05 maka dapat disimpulkan secara parsial ada pengaruh yang signifikan antara Komunikasi terhadap Kinerja Pegawai pada Dinas Perdagangan Provinsi Sumatera Selatan. Hasil Pengujian hipotesis uji $t$ Lingkungan Kerja $\left(\mathrm{X}_{2}\right)$ terhadap Kinerja Pegawai $(\mathrm{Y})$ diperoleh nilai signifikan 0,006 < $\alpha$ signifikan 0,05 maka dapat disimpulkan secara parsial ada pengaruh yang signifikan antara Lingkungan Kerja terhadap Kinerja Pegawai pada Dinas Perdagangan Provinsi Sumatera Selatan. Hasil pengujian hipotesis uji $\mathrm{F}$ diperoleh nilai signifikan $0,000<\alpha 0,05$ maka hipotesis $\mathrm{Ha}$ (Hipotesis alternatif) diterima dan Ho (Hipotesis nol) ditolak, maka dapat disimpulkan bahwa secara bersama-sama ada pengaruh yang signifikan antara Komunikasi dan Lingkungan Kerja terhadap Kinerja Pegawai pada Dinas Perdagangan Provinsi Sumatera Selatan.
\end{abstract}

Kata Kunci: Komunikasi , Lingkungan Kerja, Kinerja Pegawai

\begin{abstract}
The research method used is quantitative research methods, with a population of all 69 employees of the Office of Trade in the Province of South Sumatra. The sample used in this study used a saturated sampling technique in order to obtain a sample of 69 employees. The data collection technique was carried out by observation and questionnaires. The data analysis technique used multiple linear regression analysis, coefficient of determination, hypothesis testing $t$ test and $F$ test. The results of this study can be seen that the value of the multiple linear regression equation $Y=16.497+0.443 X 1+$ $0.583 X 2+e$. The coefficient of determination shows that the value of $R$ Square is 0.508 or $50.8 \%$, which means that the contribution of the influence of Communication (X1) and the Work Environment (X2) on Employee Performance ( $Y$ ) is 50.8\%. The results of testing the $t$ test hypothesis Communication (X1) on Employee Performance $(Y)$ obtained a significant value of $0.014<\alpha$ significant 0.05 , it can be concluded that partially there is a significant influence between Communication on Employee Performance at the South Sumatra Province Trade Office. The results of the $t$-test hypothesis testing for the Work Environment (X2) on Employee Performance (Y) obtained a significant value of $0.006<\alpha$ significant 0.05 , it can be concluded that partially there is a significant influence between the Work Environment on Employee Performance at the South Sumatra Province Trade Office. The results of testing the $F$ test hypothesis obtained a significant value of $0.000<\alpha 0.05$, then the hypothesis $\mathrm{Ha}$ (alternative hypothesis) is accepted and Ho (null hypothesis) is rejected, it can be concluded that together there is a significant influence between Communication and Work Environment on Employee Performance. at the Trade Office of South Sumatra Province.
\end{abstract}

Keywords: Communication, Work Environment, Employee Performance 


\section{A. PENDAHULUAN}

Lingkungan kerja adalah segala sesuatu yang ada didalam ruang lingkup lingkungan tempat pegawai bekerja, maka dari itu pihak instansi harus menyediakan lingkungan kerja yang memadai seperti tata ruang kantor yang nyaman, lingkungan yang bersih, pertukaran udara yang baik, penerangan yang cukup, maupun hubungan sosial atau pola komunikasi antar sesama pegawai. Lingkungan kerja yang baik dapat mendukung pelaksanaan kerja sehingga pegawai semangat bekerja dan meningkatkan kinerja pegawai. Menurut Sunyoto (2015:38), Lingkungan kerja merupakan bagian yang sangat penting ketika pegawai melakukan kegiatan bekerja. Jika lingkungan kerja baik dan nyaman, maka akan membuat pegawai menjadi termotivasi untuk bekerja secara maksimal.

Kinerja adalah hasil kerja yang dicapai atau diraih oleh seorang pegawai dalam melaksanakan tanggung jawab dan tugas yang diberikan kepadanya. Setiap organisasi atau instansi akan berusaha meningkatkan kinerja pegawai untuk mencapai tujuan organisasi yang telah ditetapkan. Oleh karena itu upaya-upaya untuk meningkatkan kinerja pegawai merupakan tantangan manajemen yang paling serius karena keberhasilan untuk mencapai tujuan dan kelangsungan hidup instansi tergantung pada kinerja sumber daya manusia yang ada didalamnya. Menurut Wibowo (2011:147) mengemukakan kinerja pegawai ialah aktivitas pegawai untuk mencapai tujuan instansi dan juga merupakan hasil kerja pegawai dari standar kerja yang telah ditentukan oleh instansi, tujuan adalah suatu hasil yang akan diperoleh di masa yang akan datang dan biasanya telah menetapkan dalam waktu yang terbatas.

Berdasarkan observasi sementara pada Dinas Perdagangan Provinsi Sumatera Selatan masih ditemukan mengenai kurangnya komunikasi antar sesama pegawai dan pimpinan dalam bekerja, serta lingkungan kerja yang kurang baik dan nyaman bagi pegawai. Sehingga dapat mengakibatkan kinerja pegawai menurun yang disebabkan komunikasi di dalam lingkungan kerja kurang baik.

Kinerja pegawai dianggap sangat penting untuk hal itu maka diperlukan pegawai yang mempunyai kinerja atau prestasi kerja yang baik karena kinerja pegawai tidak akan mencapai hasil yang maksimal apabila tidak ada hubungan yang harmonis antar sesama pegawai maupun atasan dan serta suasana yang nyaman bagi pegawai. Karena hubungan yang harmonis dan suasana yang nyaman merupakan suatu sebab yang memotivasi kinerja pegawai dalam bekerja.

\section{B. KAJIAN TEORI}

1. Komunikasi

a) Pengertian Komunikasi

$>$ Pengertian Komunikasi

Komunikasi adalah hubungan antara dua orang atau lebih dalam proses pemindahan informasi, ide, masukan, pesan dan sebagainya melalui adaptasi maupun dengan cara berkomunikasi secara lisan dan tulisan.

$>\quad$ Faktor Faktor Yang Mempengaruhi Komunikasi

Menurut Mangkunegara (2015:148-150), ada 2 faktor yang mempengaruhi komunikasi, yaitu faktor dari pihak pengirim atau disebut pula komunikator atau sender, dan dari pihak penerima atau komunikan atau receiver.

b) Faktor dari pihak pengirim (Komunikator)

1. Keterampilan komunikator 
Komunikator sebagai pengirim informasi, ide, berita, pesan perlu menguasai cara-cara penyampaian pikiran baik secara tertulis atau lisan

2. Sikap komunikator

Sikap komunikator sangat berpengaruh terhadap komunikan,komunikator yang memiliki sikap tidak sopan mengakibatkan komunikan menjadi tidak percaya akan informasi yang diberikan oleh komunikator.

3. Pengetahuan komunikator

Komunikator harus mempunyai pengetahuan yang luas dan menguasai materi yang akan diberikan kepada komunikan agar komukikan mampu memahami informasi yang diberikan.

4. Media saluran yang digunakan oleh komunikator

Media saluran komunikator sanagat berperan penting dalam menarik perhatian komunikan, komunikan harus menggunakan media saluran yang sesuai sehingga mampu menyampaikan ide, informasi atau gagasan dengan baik dan benar.

c) Faktor dari pihak penerima (Komunikan)

1. Keterampilan komunikan

Keterampilan komunikan dalam mendengarkan dan membaca pesan atau informasi sangatlah penting, sehingga pesan yang disampaikan komunikator mampu dipahami dengan baik dan benar, jika komunikan tidak memiliki keterampilan mendengar dan membaca yang baik maka komunikan tidak bisa memahami apa yang dimaksud oleh komunikator.

2. Sikap komunikan

Sikap komunikan terhadap komunikator sangat mempengaruhi berhasil tidaknya suatu komunikasi, misalnya sikap komunikan buruk seperti meremehkan, berprasangka buruk terhadap komunikator, maka komunikasi menjadi tidak efektif dan informasi yang disampaikan menjadi tidak berarti. Oleh sebab itu komunikan harus bepikiran positif kepada komunikator, meskipun pendidikan ataupun jabatan komunikator lebih rendah dibandingkan komunikan.

3. Pengetahuan komunikan

Pengetahuan komunikan sangat berpengaruh dalam percakapan komunikasi, komunikan yang memiliki pengetahuan yang luas akan lebih mudah untuk memahami informasi, ide ataupun pesan yang disampaikan oleh komunikator, jika komunikan tidak memiliki pengetahuan yang luas maka akan sulit bagi komunikan untuk memahami informasi, ide atau pesan yang diberikan oleh komunikator.

4. Media saluran komunikan

Media saluran yang digunakan oleh komunikan sangatlah berpengaruh dalam penerimaan informasi, ide ataupun pesan yang disampaikan oleh komunikator. Media saluran komunikasi berupa alat indra yang dimiliki komunikan sangatlah menentukan, apakah pesan dapat diterima dengan baik dan benar, jika alat yang dimiliki komunikan terganggu atau kurang baik maka informasi, ide atau pesan yang disampaikan menjadi kurang jelas.

d) Indikator-Indikator Komunikasi berikut:

Mangkunegara (2015:43), adapun indikator-indikator komunikasi sebagai 
1) Keterbukaan

Merupakan sikap rendah hati, jujur dan adil didalam menerima masukan dan pendapat dari orang lain.

2) Empati

Kemampuan untuk mengerti akan perasaan orang lain dan kesanggupan untuk menempatkan diri dalam keadaan orang lain.

3) Dukungan

Suatu bentuk kenyamanan, perhatian, pengharapan, ataupun bantuan yang diterima individu dari orang yang berarti, baik secara perorangan maupun kelompok.

4) Rasa positif

Bersikap positif baik ketika mengemukakan pendapat atau gagasan yang bertentangan maupun gagasan yang mendukung, karena rasa positif itu sudah dengan sendirinya mendukung proses pelaksanaan komunikasi yang efektif.

5) Kesamaan Yaitu siap menerima anggota komunikasi lain, sama atau setara".

\section{2) Lingkungan Kerja}

a) Pengertian Lingkungan Kerja

Lingkungan kerja adalah segala sesuatu yang ada disekitar pekerjaan mulai dari fasilitas suasana social antar pegawai dan mampu mempengaruhi produktivitas dan efektivitas kerja pegawai. Lingkungan kerja fisik merupakan suatu lingkungan dimana para karyawan bekerja dan dapat mempengaruhi mereka dalam menjalankan tugas - tugas yang dibebankan. (Oktariansyah, 2012:80).

A. Faktor Faktor Yang Mempengaruhi Lingkungan Kerja

Sedarmayanti (2011:28) faktor-faktor atau sebab sebab yang mempengaruhi lingkungan kerja ialah sebagai berikut:

$>$ Penerangan/cahaya ditempat kerja

Cahaya atau penerangan ditempat kerja sangat besar manfaatnya bagi pegawai guna mendapatkan keselamatan dan kelancaran kerja oleh sebab itu perlu diperhatikan adanya penerangan (cahaya) yang terang tapi tidak menyilaukan.

$>$ Temparatur ditempat kerja

Dalam keadaan normal tiap anggota tubuh manusia mempunyai temparatur yang berbeda. Tubuh manusia selalu berusaha untuk mempertahankan keadaan normal, dengan suatu sistem tubuh yang sempurna sehingga dapat menyesuaikan diri dengan perubahan yang terjadi diluar tubuh.

$>$ Kelembaban ditempat kerja

Kelembaban adalah banyaknya air yang terkandu $\mathrm{g}$ dalam udara, biasnya dinyatakan dalam persentase. Kelembaban ini berhubungan atau dipengaruhi oleh temparatur udara dan secara bersama-sama antara temparatur, kelembaban, kecepatan udara bergerak dan radiasi dari udara tersebut akan mempengaruhi keadaan tubuh manusia saat menerima atau melepaska panas dari tubuhnya.

$>\quad$ Sirkulasi udara ditempat kerja

Oksigen merupakan gas yang dibutuhkan oleh makhluk hidup untuk menjaga kelangsungan hidup, yaituuntuk proses metabolism. Udara disekitar kantor dikatakan kotor apabila kadar oksigen dalam udara tersebut telah berkurang dan telah bercampur dengan gas atau bau-bauan yang berbahaya bagi 
kesehatan tubuh. Sumber utama adanya udara segar adalah adanya tanaman disekitar temoat kerja.

$>\quad$ Kebisingan ditempat bekerja

Salah satu polusi yang yang cukup menyibukkan pakar untuk mengatasinya adalah kebisingan, yaitu bunyi yang tidak dikehendaki oleh telinga. Tidak dikehendaki karena terutama dalam jangka panjang bunyi-bunyi tersebut dapat mengganggu ketenangan bekerja, merusak pendengaran dan menimbulkan kesalahan komunikasi.

$>\quad$ Getar yang di timbulkan oleh mekanis ditempat bekerja

Getaran mekanis artinya getaran yang ditimbulkan oleh alat mekanis, yang sebagian dari getaran ini sampai ketubuh pegawai dan dapat menimbulkan akibat yang tidak diinginkan.

$>\quad$ Aroma bau tidak sedap ditempat kerja

Adanya bau-bauan disekitar tempat kerja dapat dianggap sebagai pencemaran karena dapat mengganggu konsentrasi bekerja, dan bau-bauan yang terjadi terus menerus dapat mempengaruhi kepekaan penciuman.

$>\quad$ Tata warna ditempat kerja

Menata warna ditempat kerja perlu dipelajari dan direncanakan dengan sebaikbaiknya. Sifat dan pengaruh warna kadang-kadang menimbulkan rasa senang, sedih, dll karena dalam sifat warna dapat merangsang perasaan manusia.

$>\quad$ Dekorasi ditempat kerja

Dekorasi ada hubungannya dengan tata warna yang baik, karena itu dekorasi tidak hanya berkaitan dengan hisasan ruang kerja saja tetapi berkaitan juga dengan cara mengatur tata letak, tata warna, perlengkapan dll untuk bekerja,

$>\quad$ Musik ditempat kerja

Menentukan para pakar musik, musik yang nadanya sesuai dengan suasana waktu dan tempat dapat membangkitkan dan merangsang pegawai untuk bekerja.

$>\quad$ Keamanan ditempat kerja

Guna menjaga tempat dan kondisi lingkungan kerja tetap dalam keadaan aman maka perlu diperhatikan adnya keaaman dlam bekerja. Oleh karena itu faktor keamanan perlu diwujudkan keberadaannya. Salah satu upaya untuk menjaga keamanan ditempat kerja dpat memanfaatkan tenaga satuan petuga keamanan (satpam).

B. Indikator-Indikator Lingkungan Kerja

Menurut Prihantoro (2015:36) indikator-indikator lingkungan kerja adalah sebagai berikut:

$>$ Hubungan antar pegawai

$>\quad$ Suasana kerja

$>\quad$ Tata ruang kantor

$>$ Fasilitas-fasilitas kerja pegawai.

\section{Kinerja Pegawai}

a. Pengertian Kinerja Pegawai

Kinerja pegawai adalah kesediaan seseorang atau kelompok untuk melakukan suatu kegiatan dan menyempurnakannya sesuai dengan tanggung jawabnya dengan hasil seperti yang diharapkan. 
b. Faktor-Faktor Yang Mempengaruhi Kinerja Pegawai

Menurut Zami dalam Busro (2018:95) faktor yang mempengaruhi kinerja pegawai adalah sebagai berikut.

1) Jumlah dan komposisi dari kompensasi yang diberikan, Semakin detail pekerjaan yang dihargai dengan komponsasi semakin baik pula kinerja yang disuguhkan kepada perusahaan.

2) Penempatan kerja yang tepat Semakin tepat posisi seseorang, semakin tinggi pula kinerja yang dimiliki oleh orang tersebut.

3) Pelatihan

Semakin sering diberikan pelatihan yang sesuai dengan tugas dan fungsi, maka semakin baik pula kinerja pegawaqi tersebut.

4) Promosi

Semakin jelas jenjang karier seseorang, maka semakin baik pula kinerja orang tersebut.

5) Rasa aman di masa depan

Dengan adanya pesangon dan berbagai tunjangan hari tua, maka semakin baik pula kinerja pegawai yang dimiliki perusahaan.

6) Hubungan dengan rekan kerja

Semakin baik komunikasi antar pegawai secara horizontal semakin baik pula kinerja pegawai.

7) Hubungan dengan pemimpin

Semakin baik komunikasi vertical antara pegawai dan pimpinan, maka semakin baik pula kinerja pegawai tersebut.

c. Unsur-Unsur Kinerja Pegawai

Sastrohardiwiryo (2009:12) menjelaskan bahwa umumnya unsur-unsur kinerja pegawai adalah sebagai berikut:

1) Kesetiaan

Kesetiaan yang dimaksud adalah tekad dan kesanggupan didalam mentaati, melaksanakan dan mengamalkan sesuatu yang ditaati dengan penuh kesadaran dan tanggung jawab.

2) Prestasi Kerja

Prestasi kerja merupakan hasil kerja yang dicapai oleh seorang tenaga kerja dalam melaksanakan tugas dan pekerjaan yang dibebankan kepadanya.Pada umumnya prestasi kerja seorang tenaga kerja dipengaruhi oleh kecakapan, keterampilan, pengalaman dan kesanggupan tenaga kerja yang bersangkutan.

3) Tanggung Jawab

Tanggung jawab adalah kesanggupan seorang tenaga kerja dalam menyelesaikan tugas dan pekerjaan yang diserahkan kepadanya dengan sebaik-baiknya dan tepat waktu.Serta dapat mengambil resiko atas keputusan yang diambilnya atau tindakan yang dilakukannya.

4) Ketaatan

Ketaatan adalah kesanggupan seorang tenaga kerja untuk mentaati segala aturan dan ketentuan serta peraturan perundang-undang yang berlaku, mentaati peraturan kedinasan yang diberikan oleh atasan yang berwenang, serta kesanggupan untuk tidak melanggar larangan yang ditentukan oleh perusahaan maupun pemerintah, baik secara tertulis maupun tidak tertulis. 
5) Kejujuran

Merupakan ketulusan hati tenaga kerja dalam melaksanakan tugas dan pekerjaan serta kemampuan untuk tidak menyalahgunakan wewenang yang telah dibebankan kepadanya.

6) Kerjasama

Merupakan kemampuan tenaga kerja untuk bekerja sama dengan orang lain dalam menyelesaikan tugas dan pekerjaan yang telah diamanatkan, sehingga mencapai daya guna dan hasil guna yang sebesar-besarnya.

7) Prakarsa

Adalah kemampuan seorang tenaga kerja untuk mengambil suatu keputusan atau tindakan yang diperlukan tanpa diperintah oleh manajemen lainnya.

8) Kepemimpinan

Adalah kemampuan yang memiliki seorang tenaga kerja untuk meyakinkan orang lain (tenaga kerja) sehingga dapat dikerahkan secara maksimal untuk melaksanakan tugas pokok. Penilaian unsur kepemimpinan bagi tenaga kerja yang mempunyai keyakinan dalam perusahaan, bagi top manajemen.

d. Indikator Kinerja Pegawai

Menurut Wibowo (2011:85-88) bahwa indikator-indikator dalam kinerja pegawai adalah :

1) Tujuan

Merupakan sesuatu keadaan yang lebih baik, yang ingin dicapai di masa yang akan dating. Dengan demikian tujuan menunjukkan arah kemana kinerja harus dilakukan.Atas dasar arah tersebut, dilakukan kinerja untuk mencapai tujuan.Untuk mencapai tujuan diperlukan kinerja individu, kelompok, dan organisasi.Kinerja individu maupun organisasi berhasil apabila dapat mencapai tujuan yang di inginkan.

2) Standar

Mempunyai arti penting karena memberitahukan kapan suatu tujuan dapat dilaksanakan.Standard merupakan suatu ukuran apakah tujuan yang diinginkan dapat tercapai.Tanpa standar tidak dapat diketahui kapan suatu tujuan tercapai.

3) Umpan balik

Merupakan masukan yang dipergunakan untuk mengukur kemajuan kinerja, standar kerja dan pencapaian tujuan.Dengan umpan balik dilakukan evaluasi terhadap kinerja dan sebagai hasilnya dapat dilakukan perbaikan kinerja.

4) Alat atau sarana

Merupakan sumber daya yang dapat dipergunakan untuk membantu menyelesaikan tujuan dengan sukses.Alat atau sarana merupakan faktor penunjang untuk pencapaian tujuan.Tanpa alat atau sarana, tugas pekerjaan spesifik tidak dapat dilakukan dan tujuan tidak dapat diselesaikan sebagaimana seharusnya.Tanpa alat tidak mungkin dapat melakukan pekerjaan.

5) Kompetensi

Merupakan persyaratan utama dalam kinerja.Kompetensi merupakan kemampuan yang dimiliki oleh seseorang menjalankan pekerjaan yang diberikan kepadanya dengan baik.Orang harus melakukan lebih dari sekedar belajar tentang sesuatu, orang harus dapat melakukan pekerjaannya dengan baik.Kompetensi memungkinkan seseorang mewujudkan tugas yang berkaitan dengan pekerjaan yang diperlukan untuk mencapai tujuan. 
6) Motif

Merupakan alasan untuk pendorong bagi seseorang untuk melaksanakan sesuatu.Pemimpin memfasilitasi motivasi kepada pegawai dengan insentif berupa uang, memberikan pengakuan, menetapkan tujuan menantang, menetapkan standar terjangkau, meminta umpan balik, memberikan kebebasan melalukan pekerjaan termasuk waktu melakukan pekerjaan, menyediakan sumber daya yang diperlukan dan menghapuskan tindakan yang mengakibatkan disintensif.

7) Peluang

Pekerja perlu mendapatkan kesempatan untuk menunjukan prestasi kerjanya.Terdapat dua faktor yang menyumbangkan pada adanya kekurangan kesempatan untuk berprestasi, yaitu ketersediaan waktu dan kemampuan untuk memenuhi syarat.

\section{Hipotesis Penelitian}

Menurut Sugiyono (2013:93) hipotesis merupakan jawaban sementara terhadap rumusan masalah penelitian, oleh karena itu rumusan masalah penelitian biasanya disusun dalam bentuk kalimat pernyataan. Dikatakan sementara, karena jawaban yang diberikan baru didasarkan pada teori yang relavan, belum didasarkan pada fakta-fakta empiris yang diperoleh melalui pengumpulan data. Jadi hipotesis juga dapat dinyatakan sebagai jawaban teoritis terhadap rumusan masalah penelitian, belum jawaban yang empirik.

Dalam kaitannya dengan Pengaruh Komunikasi dan Lingkungan Kerja Terhadap Kinerja Pegawai, maka rumusan hipotesis dalam penelitian ini adalah:

$\mathrm{H}_{1}$ :Diduga terdapat pengaruh Komunikasi terhadap Kinerja Pegawai pada Dinas Perdagangan Provinsi Sumatera Selatan.

$\mathrm{H}_{2}$ : Diduga terdapat pengaruh Lingkungan Kerja terhadap Kinerja Pegawai pada Dinas Perdagangan Provinsi Sumatera Selatan.

$\mathrm{H}_{3}$ : Diduga terdapat pengaruh Komunikasi dan Lingkungan Kerja secara bersamasama terhadap Kinerja Pegawai pada Dinas Perdagangan Provinsi Sumatera Selatan

\section{METODE PENELITIAN}

Dalam penelitian ini, peneliti menggunakan metode penelitian Kuantitatif. Sugiyono (2013:13) Metode penelitian kuantitatif yaitu metode yang digunakan untuk menentukan hubungan antar variabel dalam sebuah populasi, dan digunakan untuk meneliti pada populasi atau sampel tertentu, metode kuantitatif juga bersifat alamiah dan ada juga yang bersifat ilmiah,tujuan utama metode ini yaitu menjelaskan suatu masalah dan menghasilkan suatu kenyataan dan kebenarannya yang terjadi didalamnya.

\section{1) Variabel Penelitian}

Menurut Sugiyono (2013:59) variabel penelitian adalah suatu atribut atau sifat atau nilai dari orang, obyek, atau kegiatan yang mempunyai variasi tertentu yang ditetapkan oleh peneliti untuk dipelajari dan ditarik kesimpulannya. Variabel penelitian ini adalah sebagai berikut:

Variabel Independen

Variabel ini sering disebut dengan variabel bebas, yaitu variabel yang mempengaruhi atau yang menjadi sebab perubahannya atau timbulnya variabel 
dependen. Dalam penelitian ini variabel independen (bebas) adalah Komunikasi $\left(\mathrm{X}_{1}\right)$ dan Lingkungan Kerja $\left(\mathrm{X}_{2}\right)$.

$>\quad$ Variabel Dependen

Variabel ini sering disebut variabel terikat, yaitu variabel yang dipengaruhi atau yang menjadi akibat, karena adanya variabel independen (bebas). Dalam penelitian ini variabel dependen (terikat) adalah Kinerja Pegawai(Y).

\section{2) Definisi Operasional Variabel}

Definisi operasional variabel penelitian menurut Sugiyono (2015:38) adalah suatu atribut atau sifat atau nilai dari obyek atau kegiatan yang memiliki variasi tertentu yang terlah ditetapkan oleh peneliti untuk dipelajari kemudian ditarik kesimpulannya. Definisi operasional variabel harus dirumuskan untuk menghindari kesesatan dalam pengumpulan data.

\section{3) Populasi dan Sampel}

Jumlah Pegawai Negeri Sipil (PNS) yang ada di Dinas Perdagangan Provinsi Sumatera Selatan adalah 69 orang pegawai, maka populasi dalam penelitian ini sebanyak 69 pegawai. Dalam penelitian ini jumlah sampel sebanyak 69 orang pegawai.

\section{4) Sumber Data}

Menurut Sujarweni (2015:89) sumber data yang disesuaikan untuk pengambilan data dalam penelitian ada 2 yaitu :

\section{$>\quad$ Data primer}

merupakan data yang diperoleh dari responden melalui kuisioner, kelompok fokus dan panel atau juga data hasil wawancara penelitian dengan narasumber. Data primer yang diperoleh dari data ini harus diolah lagi sumber data yang langsung memberikan data kepada pengumpulan data.

$>\quad$ Data Sekunder

Data sekunder merupakan data yang didapat dari catatan, buku dan majalah berupa laporan perusahan, laporan pemerintah, buku-buku sebagai teori, majalah berupa dan sebagainya. Data yang diperoleh dari data sekunder ini tidak perlu diolah lagi, sumber yang tidak langsung memberikan data pada pengumpulan data.

\section{5) Teknik Pengumpulan Data}

Menurut Sugiyono (2013:224), teknik pengumpulan data merupakan langkah yang paling strategis dalam penelitian, karena tujuan utama dari penelitian adalah mendaptaka data dalam penelitian ini, teknik pengumpulan data yang penulis gunakan adalah :

\section{Kuesioner/Angket}

Kuesioner merupakan teknik pengumpulan data yang dilakukan dengan cara memberi seperangkat pertanyaan atau pernyataan tertulis kepada responden untuk dijawabnya. Kuesioner merupakan teknik pengumpulan data yang efisien bila peneliti tahu dengan pasti variabel yang akan diukur dan tahu apa yang bisa diharapkan responden. 
Observasi

Observasi digunakan bila penelitian berkenaan dengan perilaku manusia, proses kerja, gejala-gejala alam dan bila responden yang diamati tidak terlalu besar.

\section{6) Uji Coba Instrumen}

a. Uji Validitas

Menurut Riduwan (2015:211), uji validitas konstruksi dilakukan dengan analisis faktor, yaitu dengan mengkorelasikan antara skor item instrument dengan rumus Pearson Product Moment". "Kriteria pengujian dilakukan dengan cara membandingkan rhitung dengan rtabel pada taraf $\alpha=0,05$, jika hasil perhitungan ternyata rhitung $\geq$ rtabel maka butir instrumen dianggap valid, sebaliknya jika rhitung $\leq$ rtabel maka dianggap tidak valid (invalid), sehingga instrumen tidak dapat digunakan dalam penelitian.

Uji validitas pada penelitian ini menggunakan bantuan komputer program SPSS Versi 22.

\section{b. Uji Reliabilitas}

Menurut Kurniawan (2014:102) Uji Realiabilitas merupakan indeks yang menunjukkan sejauh mana suatu alat pengukur dapat dipercaya atau diandalkan. Pengukuran realibilitas dapat dilakukan dengan cara one shot pengukuran satu kali saja. Pengukuran dengan menyebar kuesioner kepada responden dengan butir pertanyaan satu kali saja, kemudian hasil skornya diukur korelasinya antara skor jawaban pada butir pertanyaan yang sama. Suatu konstruk atau variabel dikatakan reliabel apabila memberikan nilai cronbach alpha $(\alpha)>0,60$.

Uji reliabilitas pada penelitian ini menggunakan metode Cronbach Alpha di uji menggunakan bantuan SPPS 22.

\section{8) Uji Asumsi Klasik}

a. Normalitas Data

Menurut Priyatno (2016:119), uji normalitas dilakukan untuk mengetahui apakah dalam sebuah model Regrecy nilai residual memiliki distribusi normal atau tidak. Uji nomalitas dilakukan dengan menganalisis grafik secara normal plot atau histrogram yang dapat dideteksi atau dilihat dengan penyebaran data (titik) pada sumbu diagonal pada Grafik.

Pengambilan kuputusannya sebagai berikut:

$>\quad$ Jika data tersebut menyebar disekitar garis normal dan mengikuti arah garis diagonal grafik, maka data berdistribusi normal.

$>\quad$ Jika data menyebar jauh dari garis normal dan tidak mengikuti arah garis diagonal, maka data berdistribusi tidak normal.

\section{b. Uji Multikolinearitas}

Menurut Priyatno (2016:129), multikolinearitas adalah suatu keadaan dimana dua variabel independen atau lebih pada model regresi terjadi hubungan linear sempurna atau mendekati sempurna.

Pengambilan keputusan sebagai berikut :

Jika Tolerance $>0,1$ dan VIF $<10$, maka tidak terjadi multikolinearitas.

$>$ Jika Tolerance $<0,1$ dan VIF $>10$, maka terjadi multikolinearitas. 


\section{9) Heterokedastisitas}

Menurut Priyatno (2016:131), heteroskedastisitas adalah keadaan dimana terjadi ketidaksamaan varian dari residual pada model regresi". "Pengujian heterokedastisitas dilakukan dengan melihat pola titik-titik pada scatterplot.

Pengambilan keputusan sebagai berikut:

> Jika titik-titik menyebar dengan pola yang tidak jelas dan dibawah angka 0 pada sumbu $\mathrm{Y}$, maka tidak terjadi heteroskedastisitas.

> Jika titik-titik menyebar dengan pola yang jelas dan mengikuti arah sumbu $\mathrm{Y}$, maka terjadi heterokedastisitas.

\section{0) Teknik Analisis Data}

a. Analisis Regresi Linier Sederhana

Priyatno (2018:93), Analisis linier sederhana adalah analisis untuk mengetahui ada titiknya pengaruh yang signifikan antara satu variable independen dengan satu variabel dependen, untuk mengetahui bagaimana pengaruhnya (positif atau negatif), seberapa besar pengaruhnya dan untuk memprediksi nilai variabel dependen dengan menggunakan variabel independen.

Dalam penelitian ini uji analisis regresi liner sederhana digunakan untuk mengetahui pengaruh antara variabel Komunikasi $\left(\mathrm{X}_{1}\right)$ terhadap Kinerja Pegawai $(\mathrm{Y})$, dan Lingkungan kerja $\left(\mathrm{X}_{2}\right)$ terhadap Kinerja Pegawai $(\mathrm{Y})$.

\section{$Y=a+b x+e$}

Keterangan :

Y : Nilai variabel dependen

a : Nilai konstanta, yaitu nilai $Y$ jika $X=0$

b : Koefisien korelasi

$x$ : Variabel independent

e : Eror (diasumsikan nilai 0)

b. Analisis Regresi Linier Berganda

Siregar (2017:301), regresi linier berganda ialah pengembangan dari regresi linier sederhana, sama halnya dengan regresi sederhana yaitu sama-sama alat yang dapat digunakan untuk meprediksi permintaan di masa yang akan datang berdasarkan data masa lalu atau untuk mengetahui pengaruh satu atau lebih variabel bebas (independent) terhadap satu variabel tak bebas (dependent).

Dalam penelitian ini analisis regresi linier berganda dilakukan untuk mengetahui pengaruh komunikasi dan lingkungan kerja terhadap kinerja pegawai pada dinas perdagangan provinsi sumatera

$$
Y=a+b_{1} X_{1}+b_{2} X_{2}
$$

\section{Dimana:}

$\mathrm{Y}=$ Variabel terikat

$\mathrm{X}_{1}=$ Variabel bebas pertama

$\mathrm{X}_{2}=$ Variabel bebas kedua

$a$ dan $b_{1}$ dan $b_{2}=$ konstanta 
a) Koefisien Korelasi

Sugiyono (2015:183) analisis koefisien digunakan untuk membandingkan hasil pengukuran dua variabel yang berbeda agar dapat menentukan hasil hubungan antara variable.

b) Koefisien Determinasi $\left(\mathrm{R}^{2}\right)$

Menurut Siregar (2017:338), koefisien determinasi $R^{2}$ adalah angka yang menyatakan atau digunakan untuk mengetahui kontribusi sumbangan yang diberikan oleh sebuah varibel atau lebih $X$ (bebas) terhadap variabel $Y$ (terikat).

Rumus : $\mathbf{R}^{2}=(\mathbf{r})^{2} \times 100 \%$

Dimana :

$\mathrm{R}^{2}=$ Koefisien Determinasi

$r \quad=$ Kuadrat Koefisien Korelasi

\section{Pengujian Hipotesis}

a) Uji Parsial (Uji t)

Menurut Sujarweni (2015:161), uji t adalah pengujian koefisien regresi parsial individual yang digunakan untuk mengetahui apakah variabel independent $(X)$ secara individual mempengaruhi variabel dependent $(\mathrm{Y})$.

Kriteria :

Jika sig $<0,05$, maka $\mathrm{H}_{\mathrm{o}}$ ditolak dan $\mathrm{H}_{\mathrm{a}}$ diterima

Jika sig $\geq 0,05$, maka $\mathrm{H}_{0}$ diterima dan $\mathrm{H}_{\mathrm{a}}$ ditolak

\section{b) Uji Simultan (Uji F)}

Sujarweni (2015: 162), uji $\mathrm{F}$ adalah penguji signifikan persamaan yang digunakan untuk mengetahui seberapa besar pengaruh variabel bebas $(X)$ secara bersama- sama terhadap variabel tidakl bebas $(\mathrm{Y})$.

Kriteria :

Jika sig $<0,05$, maka $\mathrm{H}_{\mathrm{o}}$ ditolak dan $\mathrm{H}_{\mathrm{a}}$ diterima

Jika sig $\geq 0,05$, maka $\mathrm{H}_{\mathrm{o}}$ diterima dan $\mathrm{H}_{\mathrm{a}}$ ditolak

\section{HASIL PENELITIAN}

1. Hasil Uji Coba Instrument Penelitian

a. Hasil Uji Validitas

Uji validitas digunakan untuk menguji kuesioner. Uji validitas dilakukan dengan mengukur butir-butir pernyataan dalam kuesioner dari masing-masing variabel penelitian dengan membandingkan nilai correlated item-total correlations ( $\mathrm{r}_{\text {hitung }}$ ) dengan perhitungan ( $\left.r_{\text {tabel }}\right)$. Nilai $r_{\text {tabel }}$ pada taraf signifikan sebesar 0,05 dan jumlah data sebanyak 69 sehingga diperoleh nilai $r_{\text {tabel }}$ sebesar 0,237 $(\mathrm{df}=\mathrm{n}-\mathrm{k})$ Perhitungan nilai rhitung dapat dilihat pada tabel berikut ini:

\section{1) Uji Validitas Komunikasi}

Tabel Hasil Uji Validitas Variabel Komunikasi

\begin{tabular}{|c|c|c|c|c|c|}
\hline \multirow{2}{*}{ No } & Pernyataan & rhitung & rtabel & Kriteria & Keterangan \\
\hline & \multicolumn{5}{|c|}{ Komunikasi } \\
\hline 1 & Pernyataan 1 & 0,553 & 0,237 & $r_{\text {hitung }}>r_{\text {tabel }}$ & Valid \\
\hline 2 & Pernyataan 2 & 0,527 & 0,237 & $r_{\text {hitung }}>r_{\text {tabel }}$ & Valid \\
\hline
\end{tabular}




\begin{tabular}{cccccc}
3 & Pernyataan 3 & 0,495 & 0,237 & $r_{\text {hitung }}>r_{\text {tabel }}$ & Valid \\
4 & Pernyataan 4 & 0,655 & 0,237 & $r_{\text {hitung }}>r_{\text {tabel }}$ & Valid \\
5 & Pernyataan 5 & 0,590 & 0,237 & $r_{\text {hitung }}>r_{\text {tabel }}$ & Valid \\
6 & Pernyataan 6 & 0,646 & 0,237 & $r_{\text {hitung }}>r_{\text {tabel }}$ & Valid \\
7 & Pernyataan 7 & 0,388 & 0,237 & $r_{\text {hitung }}>r_{\text {tabel }}$ & Valid \\
8 & Pernyataan 8 & 0.680 & 0,237 & $r_{\text {hitung }}>r_{\text {tabel }}$ & Valid \\
9 & Pernyataan 9 & 0,500 & 0,237 & $r_{\text {hitung }}>r_{\text {tabel }}$ & Valid \\
10 & Pernyataan 10 & 0,389 & 0,237 & $r_{\text {hitung }}>r_{\text {tabel }}$ & Valid \\
\hline
\end{tabular}

Sumber: data diolah dengan program SPSS Versi 22

Dari Tabel diatas dapat diketahui bahwa seluruh item pernyataan pada variabel Komunikasi $\left(\mathrm{X}_{1}\right)$ adalah Valid, karena nilai rhitung $>\mathrm{r}_{\text {tabel. }}$.

\section{2) Uji Validitas Lingkungan Kerja}

Tabel Hasil Uji Validitas Lingkungan Kerja

\begin{tabular}{|c|c|c|c|c|c|}
\hline \multirow{2}{*}{ No } & Pernyataan & Yhitung & rtabel & Kriteria & Keterangan \\
\hline & \multicolumn{5}{|c|}{ Lingkungan Kerja } \\
\hline 1 & Pernyataan 1 & 0,659 & 0,237 & $r_{\text {hitung }}>r_{\text {tabel }}$ & Valid \\
\hline 2 & Pernyataan 2 & 0,717 & 0,237 & $r_{\text {hitung }}>r_{\text {tabel }}$ & Valid \\
\hline 3 & Pernyataan 3 & 0,528 & 0,237 & $r_{\text {hitung }}>r_{\text {tabel }}$ & Valid \\
\hline 4 & Pernyataan 4 & 0,732 & 0,237 & $r_{\text {hitung }}>r_{\text {tabel }}$ & Valid \\
\hline 5 & Pernyataan 5 & 0,343 & 0,237 & $r_{\text {hitung }}>r_{\text {tabel }}$ & Valid \\
\hline 6 & Pernyataan 6 & 0,598 & 0,237 & $r_{\text {hitung }}>r_{\text {tabel }}$ & Valid \\
\hline 7 & Pernyataan 7 & 0,558 & 0,237 & $r_{\text {hitung }}>r_{\text {tabel }}$ & Valid \\
\hline 8 & Pernyataan 8 & 0,735 & 0,237 & $r_{\text {hitung }}>r_{\text {tabel }}$ & Valid \\
\hline
\end{tabular}

Sumber: data diolah dengan program SPSS Versi 22

Dari Tabel diatas dapat diketahui bahwa seluruh item pernyataan pada variabel Lingkungan Kerja $\left(X_{2}\right)$ adalah Valid, karena nilai rhitung $>$ rtabel.

3) Uji Validitas Kinerja Pegawai

Tabel Hasil Uji Validitas Kinerja Pegawai

\begin{tabular}{cccccc}
\hline \multirow{2}{*}{ No } & Pernyataan & rhitung & rtabel & Kriteria & Keterangan \\
\cline { 2 - 6 } & \multicolumn{5}{c}{ Kinerja Pegawai } \\
\hline 1 & Pernyataan 1 & 0,405 & 0,237 & $r_{\text {hitung }}>r_{\text {tabel }}$ & Valid \\
2 & Pernyataan 2 & 0,630 & 0,237 & $r_{\text {hitung }}>r_{\text {tabel }}$ & Valid \\
3 & Pernyataan 3 & 0,380 & 0,237 & $r_{\text {hitung }}>r_{\text {tabel }}$ & Valid \\
4 & Pernyataan 4 & 0,508 & 0,237 & $r_{\text {hitung }}>r_{\text {tabel }}$ & Valid \\
5 & Pernyataan 5 & 0,603 & 0,237 & $r_{\text {hitung }}>r_{\text {tabel }}$ & Valid \\
6 & Pernyataan 6 & 0,651 & 0,237 & $r_{\text {hitung }}>r_{\text {tabel }}$ & Valid \\
7 & Pernyataan 7 & 0,459 & 0,237 & $r_{\text {hitung }}>r_{\text {tabel }}$ & Valid \\
8 & Pernyataan 8 & 0,521 & 0,237 & $r_{\text {hitung }}>r_{\text {tabel }}$ & Valid \\
9 & Pernyataan 9 & 0,622 & 0,237 & $r_{\text {hitung }}>r_{\text {tabel }}$ & Valid \\
10 & Pernyataan 10 & 0,348 & 0,237 & $r_{\text {hitung }}>r_{\text {tabel }}$ & Valid \\
11 & Pernyataan 11 & 0,268 & 0,237 & $r_{\text {hitung }}>r_{\text {tabel }}$ & Valid
\end{tabular}




\begin{tabular}{llllll}
12 & Pernyataan 12 & 0,302 & 0,237 & $r_{\text {hitung }}>r_{\text {tabel }}$ & Valid \\
13 & Pernyataan 13 & 0,378 & 0,237 & $r_{\text {hitung }}>r_{\text {tabel }}$ & Valid \\
14 & Pernyataan 14 & 0,288 & 0,237 & $r_{\text {hitung }}>r_{\text {tabel }}$ & Valid \\
\hline
\end{tabular}

Sumber: data diolah dengan program SPSS Versi 22

Dari Tabel diatas dapat diketahui bahwa seluruh item pernyataan pada variabel Kinerja Pegawai $(Y)$ adalah Valid, karena nilai rhitung $>r_{\text {tabel. }}$

\section{b. Hasil Uji Reliabilitas}

Uji reliabilitas digunakan untuk mengetahui apakah indikator atau kuesioner yang digunakan dapat dipercaya atau handal sebagai alat ukur variabel. Realibilitas suatu indikator atau kuesioner dapat dilihat dari nilai Cronbach Alpha ( $\alpha$ ), apabila nilai Cronbach Alpha $(\alpha)>0,60$ maka indikator atau kuesioner tersebut reliabel, sedangkan apabila nilai Cronbach Alpha $(\alpha)<0,60$, maka indikator atau kuesioner tidak reliabel. Pengujian realibilitas instrument penelitian dapat dilihat pada tabel berikut ini:

\section{1) Uji Reliabilittas Variabel Komunikasi}

Tabel Hasil Uji Reliabilitas Variabel Komunikasi

Sumber: data diolah dengan program SPSS Versi 22

Hasil uji reliabilitas berdasarkan tabel diatas pada variabel Komunikasi didapat nilai Cronbach Alpha sebesar 0,732 >0,60 karena nilai tersebut diatas 0,60 maka dapat disimpulkan bahwa alat ukur dalam penelitian ini reliabel (dapat dipercaya) dan dapat dijadikan alat ukur di analisis selanjutnya.

\section{2) Uji Relibilitas Variabel Lingkungan Kerja}

\section{Tabel Hasil Uji Variabel Lingkungan kerja}

\begin{tabular}{cc}
\multicolumn{3}{c}{ Reliability statistics } \\
\hline $\begin{array}{c}\text { Cronbach's } \\
\text { Alpha }\end{array}$ & $\begin{array}{c}\mathbf{N} \text { of } \\
\text { items }\end{array}$ \\
\hline, 749 & 9 \\
\hline tiolah dengan program SPSS Versi 22
\end{tabular}

Hasil uji reliabilitas berdasarkan tabel diatas pada variabel Lingkungan Kerja didapat nilai Cronbach Alpha sebesar 0,749 >0,60 karena nilai tersebut diatas 0,60 maka dapat disimpulkan bahwa alat ukur dalam penelitian ini reliabel (dapat dipercaya) dan dapat dijadikan alat ukur di analisis selanjutnya. 


\section{3) Uji Reliabilitas Variabel Kinerja Pegawai}

Tabel Hasil Uji Reliabilitas Variabel Kinerja Pegawai

\begin{tabular}{cc}
\multicolumn{3}{c}{ Reliability Statistics } \\
\cline { 2 - 3 } $\begin{array}{c}\text { Cronbach's } \\
\text { Alpha }\end{array}$ & $\begin{array}{c}\mathrm{N} \text { of } \\
\text { ltems }\end{array}$ \\
\cline { 2 - 3 } Sumber: data diolah dengan program SPSS Versi 22
\end{tabular}

Hasil uji reliabilitas berdasarkan tabel diatas pada variabel Kinerja Pegawai didapat nilai Cronbach Alpha sebesar 0,704 >0,60 karena nilai tersebut diatas 0,60 maka dapat disimpulkan bahwa alat ukur dalam penelitian ini reliabel (dapat dipercaya) dan dapat dijadikan alat ukur di analisis selanjutnya.

\section{Hasil Uji Asumsi Klasik}

\section{a. Uji Normalitas}

Uji normalitas akan menguji data Variabel bebas $(X)$ dan data Variabel terikat (Y) pada persamaaan Regresi yang dihasilkan, apakah berdistribusi normal atau tidak normal. Uji normalitas dapat dilakukan dengan cara analisis grafik histogram dan normal Probability plots yang dapat dideteksi dengan melihat penyebaran data (titik) pada sumbu Diagonal dari Grafik. Uji normalitas pada penelitian ini menggunakan uji normalitas Probability plots

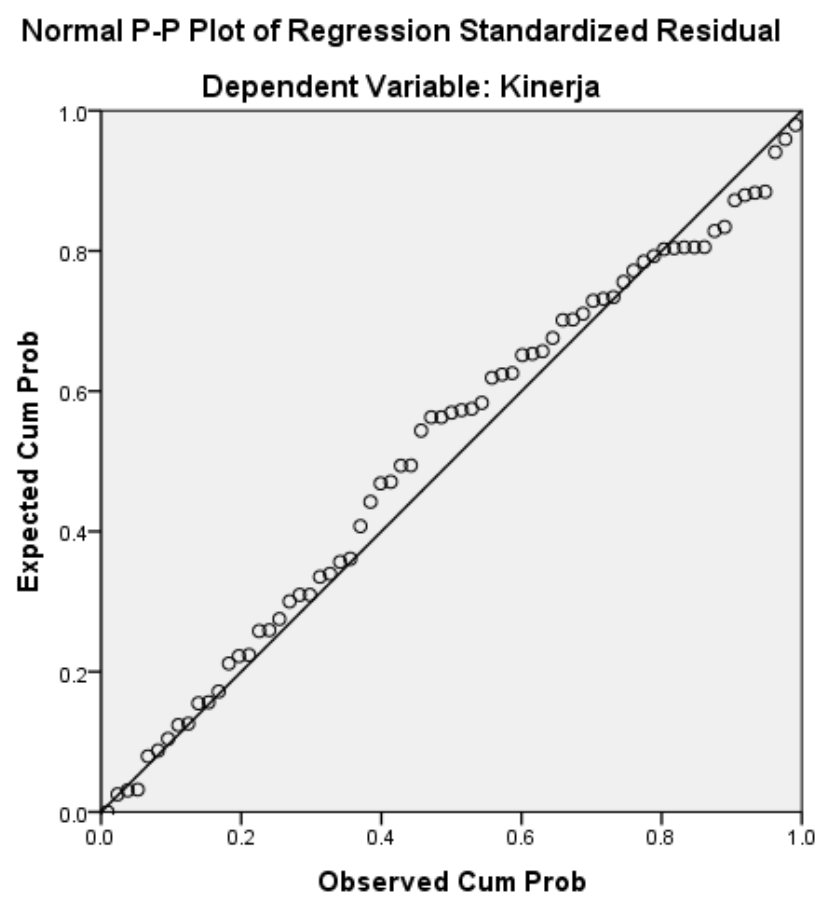

Sumber: Data diolah dengan program SPSS versi 22 Gambar Hasil Uji Normalitas

Hasil pengujian normalitas pada gambar diatas menunjukkan bahwa titik-titik menyebar tidak jauh dan mengikuti dari grafik diagonal. Hal ini menunjukkan bahwa model regresi tersebut sudah berdistribusi normal. 


\section{b. Uji Multikolinearitas}

Uji Multikolinearitas berarti ada hubungan linear yang sempurna atau pasti diantara bebarapa atau semua variabel yang independent dari model yang ada. Akibat adanya multikolinearitas ini koefisien regresi tidak bertemu dan kesalahan standarnya tidak terhingga. Multikolinearitas bertujuan untuk menguji apakah pada model regresi yang baik seharusnya tidak terjadi korelasi di antara variabel bebas. Metode untuk menguji adanya multikolinearitas ini dapat dilihat dari tolerance value atau variance inflantion factor (VIP) sebagai berikut:

$>$ Jika Tolerance $>0,1$ dan VIF $<10$, maka tidak terjadi multikolinearitas.

$>$ Jika Tolerance $<0,1$ dan VIF $>10$, maka terjadi multikolinearitas.

\begin{tabular}{|c|c|c|}
\hline \multirow[b]{2}{*}{ Model } & \multicolumn{2}{|c|}{ Collinerity Statistics } \\
\hline & Tolerance & VIF \\
\hline 1 (Constant) & & \\
\hline Komunikasi &, 565 & 1,769 \\
\hline Lingkungan kerja &, 565 & 1,769 \\
\hline
\end{tabular}

Berdasarkan tabel diatas, variabel Konflik Kerja diperoleh nilai Tolerance $\mathbf{0 , 5 6 5}<\mathbf{0 , 1 0}$ dan nilai VIF (Variance Inflation Factor) 1,769 > 10. Dan variabel Stres Kerja diperoleh nilai Tolerance 0,565 $<0,10$ dan nilai VIF (Variance Inflation Factor) 1,769 > 10. Pada data diatas menunjukkan bahwa Komunikasi dan Lingkungan Kerja tidak terjadi multikolinearitas.

\section{c. Uji Heterokedastisitas}

Uji Heterokedastisitas adalah suatu keadaan dimana varian dan kesalahan pengganggu tidak konstan untuk semua variabel bebas. Model regresi yang baik adalah tidak terjadi heterokedastisitas. Uji heterokedastisitas dilakukan dengan melihat pola garis scatterplot.

Pengambilan keputusan dilakukan apabila:

1) Jika titik-titik hasil pola menyebar diatas dan dibawah maka angka nol pada sumbu $Y$, maka tidak terjadi heterokedastisitas.

2) Jika tititk-titik menyebar dengan pola yang jelas dan mengikuti arah sumbu $Y$, maka terjadi heterokedastisitas. 


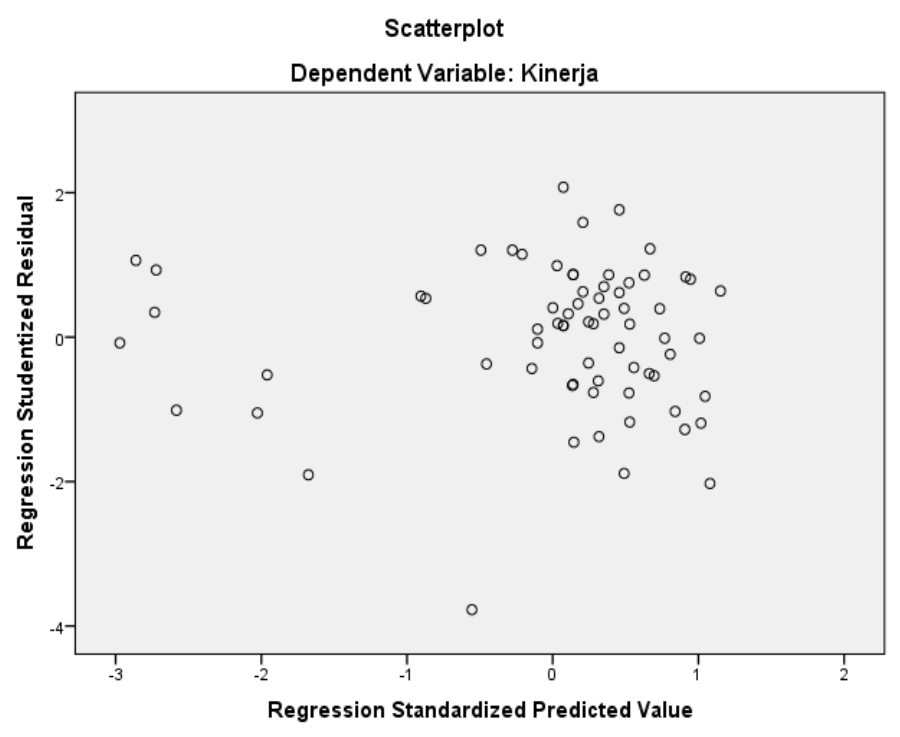

Gambar Hasil Uji Heterokedastisitas

Sumber: Data diolah dengan program SPSS versi 22

Pada gambar diatas terlihat hasil pola menyebar diatas dan dibawah angka nol pada sumbu Y. Hal ini menunjukkan bahwa tidak terjadi heterokedastisitas.

\section{Teknik Hasil Analisis Data}

1) Analisis Deskriptif

Data yang digunakan dalam penelitian ini menggunakan data Primer. Data Primer adalah data yang didapatkan secara langsung dari suatu objek yang diteliti. Sedangkan proses pengambilan data tersebut adalah menggunakan kuisiner yang dibagikan kepada 69 pegawai di Dinas Perdagangan Provinsi Sumatera Selatan. Angket yang dibagikan terdiri dari butir-butir pernyataan yang diberikan kepada seluruh responden yang bertindak sebagai sampel, terdiri dari Variabel Komunikasi, Lingkungan kerja dan Kinerja pegawai.

\section{Tabel Distribusi}

a. Tabel Distribusi Komunikasi $\left(X_{1}\right)$

\begin{tabular}{cccccccc}
\hline No & Pernyataan & SS & S & RR & TS & STS & Jumlah \\
& & 5 & 4 & 3 & 2 & 1 & \\
\hline 1 & Responden 1 & 17 & 33 & 13 & 1 & 5 & 100 \\
& & $24,6 \%$ & $47,9 \%$ & $18.9 \%$ & $1,4 \%$ & $7,2 \%$ & \\
2 & Responden 2 & 20 & 39 & 7 & 0 & 3 & 100 \\
& & $28,9 \%$ & $56,5 \%$ & $10,2 \%$ & $0,0 \%$ & $4,4 \%$ & \\
3 & Responden 3 & 12 & 48 & 7 & 0 & 2 & 100 \\
& & $17,3 \%$ & $69,6 \%$ & $10,2 \%$ & $0,0 \%$ & $2,9 \%$ & \\
4 & Responden 4 & 22 & 36 & 6 & 1 & 4 & 100 \\
& & $31,9 \%$ & $52,2 \%$ & $8,7 \%$ & $1,4 \%$ & $5,8 \%$ & \\
5 & Responden 5 & 9 & 43 & 15 & 1 & 1 & 100 \\
& & $13, \%$ & $62,3 \%$ & $21,8 \%$ & $1,4 \%$ & $1,4 \%$ & \\
6 & Responden 6 & 15 & 38 & 9 & 3 & 4 & 100 \\
& & $21,7 \%$ & $55,0 \%$ & $13,1 \%$ & $4,4 \%$ & $5,8 \%$ & \\
7 & Responden 7 & 18 & 37 & 10 & 3 & 1 & 100 \\
& & $26,0 \%$ & $53,7 \%$ & $14,5 \%$ & $4,4 \%$ & $1,4 \%$ & \\
& & & & & & &
\end{tabular}




\begin{tabular}{cccccccc}
8 & Responden 8 & 21 & 33 & 10 & 2 & 3 & 100 \\
& & $30,4 \%$ & $47,9 \%$ & $21,8 \%$ & $5,8 \%$ & $4,4 \%$ & \\
9 & Responden 9 & 16 & 33 & 15 & 4 & 1 & 100 \\
& & $23,1 \%$ & $47,9 \%$ & $21,8 \%$ & $5,8 \%$ & $1,4 \%$ & \\
10 & Responden 10 & 22 & 36 & 10 & 0 & 1 & 100 \\
& & $31,9 \%$ & $52,2 \%$ & $14,5 \%$ & $0,0 \%$ & $1,4 \%$ & \\
\hline
\end{tabular}

\section{Tabel Distribusi}

b. Tabel Distribusi Lingkungan Kerja $\left(\mathrm{X}_{2}\right)$

\begin{tabular}{cccccccc}
\hline No & Pernyataan & SS & S & RR & TS & STS & Jumlah \\
& & 5 & 4 & 3 & 2 & 1 & \\
\hline 1 & Responden 1 & 18 & 41 & 4 & 4 & 2 & 100 \\
& & $26,1 \%$ & $59,4 \%$ & $5,8 \%$ & $5,8 \%$ & $2,9 \%$ & \\
2 & Responden 2 & 19 & 43 & 2 & 4 & 1 & 100 \\
& & $27,5 \%$ & $52,3 \%$ & $2,9 \%$ & $5,8 \%$ & $1,4 \%$ & \\
3 & Responden 3 & 14 & 48 & 5 & 1 & 1 & 100 \\
& & $20,3 \%$ & $69,6 \%$ & $7,2 \%$ & $1,4 \%$ & $1,4 \%$ & \\
4 & Responden 4 & 25 & 31 & 8 & 5 & 0 & 100 \\
& & $36,2 \%$ & $44,9 \%$ & $11,6 \%$ & $7,2 \%$ & $0,0 \%$ & \\
5 & Responden 5 & 29 & 31 & 4 & 5 & 0 & 100 \\
& & $42,1 \%$ & $49,9 \%$ & $5,8 \%$ & $7,2 \%$ & $0,0 \%$ & \\
6 & Responden 6 & 20 & 32 & 8 & 9 & 0 & 100 \\
& & $28,9 \%$ & $46,3 \%$ & $11,6 \%$ & $13,1 \%$ & $0,0 \%$ & \\
7 & Responden 7 & 18 & 39 & 9 & 1 & 2 & 100 \\
& & $26,0 \%$ & $56.5 \%$ & $13,1 \%$ & $1,4 \%$ & $2,9 \%$ & \\
8 & Responden 8 & 17 & 41 & 6 & 3 & 2 & 100 \\
& & $24,6 \%$ & $59,4 \%$ & $8,7 \%$ & $4,4 \%$ & $2,9 \%$ & \\
\hline
\end{tabular}

\section{Tabel Distribusi}

\section{c. Tabel Distribusi Kinerja Pegawai (Y)}

\begin{tabular}{cccccccc}
\hline No & Pernyataan & SS & S & RR & TS & STS & Jumlah \\
& & 5 & 4 & 3 & 2 & 1 & \\
\hline 1 & Responden 1 & 14 & 37 & 11 & 5 & 2 & 100 \\
& & $20,3 \%$ & $53,7 \%$ & $15,9 \%$ & $7,2 \%$ & $2,9 \%$ & \\
2 & Responden 2 & 16 & 40 & 5 & 4 & 4 & 100 \\
& & $23,1 \%$ & $58,1 \%$ & $7,2 \%$ & $5,8 \%$ & $5,8 \%$ & \\
3 & Responden 3 & 14 & 44 & 9 & 1 & 1 & 100 \\
& & $20,3 \%$ & $63,8 \%$ & $13,1 \%$ & $1,4 \%$ & $1,4 \%$ & \\
4 & Responden 4 & 25 & 35 & 1 & 4 & 4 & 100 \\
& & $36,2 \%$ & $50,8 \%$ & $1,4 \%$ & $5,8 \%$ & $5,8 \%$ & \\
5 & Responden 5 & 28 & 29 & 4 & 4 & 4 & 100 \\
& & $40,5 \%$ & $42,1 \%$ & $5,8 \%$ & $5,8 \%$ & $5,8 \%$ & \\
6 & Responden 6 & 19 & 31 & 11 & 4 & 4 & 100 \\
& & $27,5 \%$ & $44,9 \%$ & $15,9 \%$ & $4,8 \%$ & $5,8 \%$ & \\
7 & Responden 7 & 19 & 35 & 11 & 2 & 2 & 100 \\
& & $27,5 \%$ & $50,8 \%$ & $15,9 \%$ & $2,9 \%$ & $2,9 \%$ & \\
8 & Responden 8 & 23 & 28 & 13 & 3 & 2 & 100 \\
& & $33,9 \%$ & $40,5 \%$ & $18,9 \%$ & $4,4 \%$ & $2,9 \%$ & \\
9 & Responden 9 & 19 & 31 & 13 & 2 & 4 & 100 \\
& & $27,5 \%$ & $44,9 \%$ & $18,9 \%$ & $2,9 \%$ & $5,8 \%$ & \\
10 & Responden 10 & 19 & 27 & 16 & 7 & 0 & 100 \\
\hline
\end{tabular}




\begin{tabular}{cccccccc}
\hline & & $27,5 \%$ & $39,2 \%$ & $23,1 \%$ & $10,2 \%$ & $0,0 \%$ & \\
11 & Responden 11 & 18 & 14 & 14 & 4 & 19 & 100 \\
& & $26,1 \%$ & $20,3 \%$ & $20,3 \%$ & $5,8 \%$ & $27,5 \%$ & \\
12 & Responden 12 & 7 & 22 & 28 & 11 & 1 & 100 \\
& & $10,2 \%$ & $31,9 \%$ & $40,5 \%$ & $15,9 \%$ & $1,4 \%$ & \\
13 & Responden 13 & 22 & 26 & 12 & 6 & 3 & 100 \\
& & $37,7 \%$ & $31,9 \%$ & $17,3 \%$ & $8.7 \%$ & $4,4 \%$ & \\
14 & Responden 14 & 20 & 14 & 12 & 7 & 16 & 100 \\
& & $28,9 \%$ & $20,3 \%$ & $17,3 \%$ & $10,2 \%$ & $23,1 \%$ & \\
\hline
\end{tabular}

\section{2) Analisis Regresi Linier Sederhana}

Analisis persamaan regresi linier sederhana digunakan untuk mengetahui pengaruh atau hubungan secara linier antara satu variabel independent dengan satu variabel dependent.

Persamaan regresi dalam penelitian ini adalah untuk mengetahui seberapa besar pengaruh Komunikasi $\left(\mathrm{X}_{1}\right)$ terhadap Kinerja Pegawai $(\mathrm{Y})$ dan Lingkungan Kerja $\left(\mathrm{X}_{2}\right)$ terhadap Kinerja Pegawai $(\mathrm{Y})$. Perhitungan analisis regresi linier sederhana menggunakan bantuan aplikasi SPSS Versi 22 sebagai berikut :

\section{Tabel Hasil Analisis Persamaan Regresi Linier Sederhana Komunikasi $\left(\mathbf{X}_{1}\right)$ Terhadap Kinerja Pegawai (Y)}

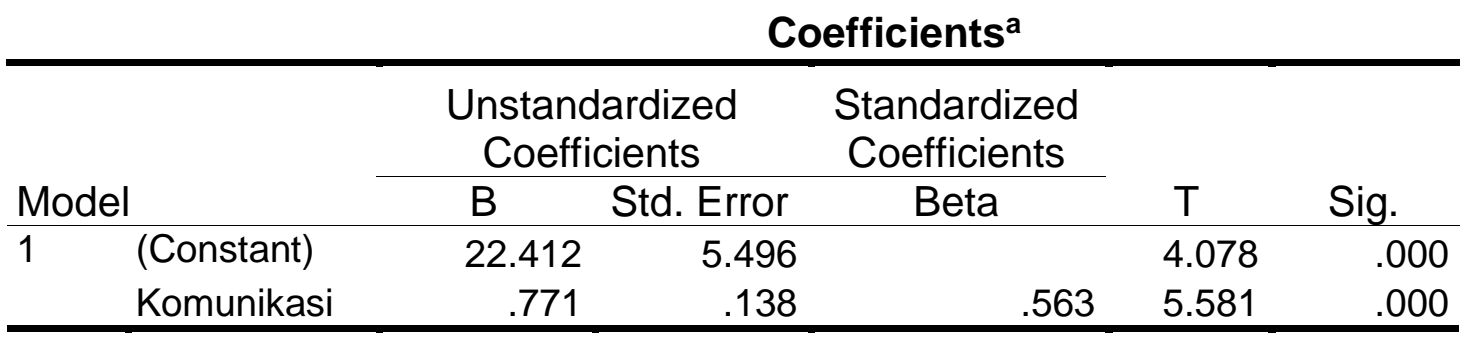

a. Dependent Variable: Kinerja

Sumber:Hasil Pengelolaan Data Dengan Program SPSS Versi 22

Berdasarkan hasil pengujian regresi linier sederhana diatas diperoleh nilai koefisien untuk Komunikasi $\left(\mathrm{X}_{1}\right)$ Sebesar 0,771 dan nilai konstanta Kinerja Pegawai (Y) sebesar 22,412.

Berdasarkan nilai tersebut, maka diperoleh persamaan regresi linier sederhana adalah $\mathrm{Y}=22,421+0,771$.

Tabel Hasil Analisis Persamaan Regresi Linier Sederhana Lingkungan Kerja

$\left(X_{2}\right)$ Terhadap Kinerja Pegawai $(Y)$

Coefficients $^{\mathrm{a}}$

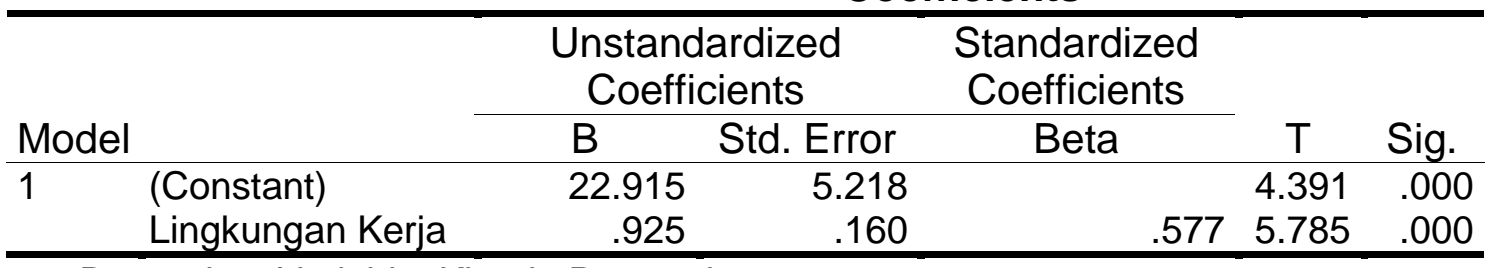

a. Dependent Variable: Kinerja Pegawai

Sumber : Hasil Pengelolaan Data Dengan Program SPSS Verso 22 
Berdasarkan hasil pengujian regresi linier sederhana diatas diperoleh nilai koefisien regresi untuk Lingkungan Kerja $\left(\mathrm{X}_{2}\right)$ sebesar 0,925 dan nilai konstanta Kinerja Pegawai (Y) sebesar 22,915.

Berdasarkan nilai tersebut, maka diperoleh persamaan regresi linier sederhana adalah $\mathrm{Y}=22,915+0,925$.

\section{3) Analisis Regresi Linear Berganda}

Analisis Regresi Linear berganda bertujuan untuk mengetahui apakah ada hubungan antara Variabel $X_{1}$ dan $X_{2}$ terhadap variabel $Y$ dimana ketiga variabel tersebut Komunikasi dan Lingkungan Kerja sebagai Variabel bebas, dan Kinerja Pegawai sebagai Variabel terikat. Hasil uji Regresi linear Berganda dapat di lihat pada tabel berikut ini:

\section{Tabel Hasil Uji Regresi Linier Berganda Coefficients $^{\mathrm{a}}$}

\begin{tabular}{lrrr}
\hline & \multicolumn{2}{c}{$\begin{array}{l}\text { Unstandardized } \\
\text { Coefficients }\end{array}$} & \multicolumn{2}{c}{$\begin{array}{c}\text { Standardized } \\
\text { Coefficients }\end{array}$} \\
\cline { 2 - 4 } Model & \multicolumn{1}{c}{ B } & Std. Error & Beta \\
\hline (Constant) & 16,497 & 5,621 & \\
Komunikasi &, 443 &, 175 &, 323 \\
Lingkungan Kerja &, 583 &, 204 &, 354 \\
\hline
\end{tabular}

a. Dependent Variable: Kinerja Pegawai

Sumber: Data diolah dengan SPSS versi 22

Berdasarkan hasil pengujian regresi linier berganda diatas diperoleh nilai koefisien regresi untuk Komunikasi $\left(X_{1}\right)$ sebesar 0,443 dan nilai koefisien regresi untuk Lingkungan Kerja $\left(X_{2}\right)$ sebesar 0,583 dan nilai konstanta sebesar 16,497.

Berdasarkan nilai tersebut, maka diperoleh persamaan regresi linier berganda adalah $Y=16,497+0,443 X_{1+0,583 X_{2}+e}$

\section{Hasil Pengujian Koefisien}

a. Hasil Pengujian Koefisien Hasil Analisis Koefisien Korelasi

Analisis koefisien digunakan untuk membandingkan hasil pengukuran dua variabel yang berbeda agar dapat menentukan hasil hubungan antara variabel.

Hasil Pengujian Koefisien Korelasi. Model Summary

\begin{tabular}{llrrr}
\hline Model & $\mathrm{R}$ & $\mathrm{R}$ Square & $\begin{array}{c}\text { Adjusted R } \\
\text { Square }\end{array}$ & $\begin{array}{r}\text { Std. Error of } \\
\text { the Estimate }\end{array}$ \\
\hline 1 &, $626^{\mathrm{a}}$ &, 392 &, 374 & 5,300 \\
\hline
\end{tabular}

a. Predictors: (Constant), X2, X1

Sumber: Data diolah dengan SPSS versi 22

Dari hasil tabel diatas, diketahui bahwa nilai koefisien korelasi $(R)$ anatara komunikasi dan lingkungan kerja terhadap kinerja pegawai adalah sebesar 0,626. 


\section{b. Hasil Analisis Koefisien Determinasi $\left(\mathbf{R}^{2}\right)$}

Koefisien Determinasi $\left(\mathrm{R}^{2}\right)$ adalah angka yang menyatakan atau digunakan untuk mengetahui kontribusi atau sumbangan yang diberikan oleh satu atau lebih variabel $X$ (bebas) terhadap variabel $Y$ (terikat). Hasil pengujian Koefisien Determinasi dapat dilihat pada tabel dibawah ini:

Tabel Hasil Analisi Koefisien Determinasi Model Summary

\begin{tabular}{llrrrr}
\hline Model & $\mathrm{R}$ & $\begin{array}{c}\mathrm{R} \\
\text { Square }\end{array}$ & $\begin{array}{c}\text { Adjusted R } \\
\text { Square }\end{array}$ & $\begin{array}{r}\text { Std. Error of } \\
\text { the Estimate }\end{array}$ \\
\hline 1 &, $626^{\mathrm{a}}$ &, 392 &, 374 & 5,300 \\
\hline
\end{tabular}

a. Predictors: (Constant), X2, X1

Sumber: Data diolah dengan SPSS versi 22

Dari tabel diatas diketahui bahwa nilai koefisien determinasi $R$ Square $\left(R^{2}\right)$ sebesar 0,392 atau $39,2 \%$ dan sisanya $(100 \%$ - 39,2\%) $0,608 \%$ dipengaruhi oleh faktor-faktor lain yang tidak masuk dalam penelitian ini.

\section{c. Hasil Uji Hipotesis}

1) Hasil Uji t

Uji t biasanya dapat digunakan untuk mengetahui independent $(X)$ secara Parsial berpengaruh signifikan terhadap variabel dependen $(\mathrm{Y})$. Taraf signifikan yang digunakan adalah 0,05 atau $5 \%$. Signifikan artinya meyakinkan atau pengaruh yang terjadi dapat berlaku untuk populasi. Hasil uji t dapat dilihat pada tabel berikut ini:

\begin{tabular}{|c|c|c|c|c|c|}
\hline \multicolumn{6}{|c|}{$\begin{array}{c}\text { Tabel Hasil Uji t } \\
\text { Coefficients }^{\mathrm{a}}\end{array}$} \\
\hline & $\begin{array}{l}\text { Unstand } \\
\text { Coeffi }\end{array}$ & $\begin{array}{l}\text { ardized } \\
\text { ients }\end{array}$ & $\begin{array}{l}\text { Standardized } \\
\text { Coefficients }\end{array}$ & & \\
\hline Model & $B$ & Std. Error & Beta & $\mathrm{t}$ & Sig. \\
\hline (Constant) & 16,497 & 5,621 & & 2,935 &, 005 \\
\hline Komunikasi & ,443 & , 175 & ,323 & 2,535 & 014 \\
\hline Lingkungan Kerja & ,583 & ,204 & ,364 & 2,852 &, 006 \\
\hline
\end{tabular}

a. Dependent Variable: Kinerja pegawai

Sumber: Data diolah dengan program SPSS Versi 22

Uji t pada tabel diatas untuk menguji pengaruh tiap variabel independen terhadap variabel dependen dengan membandingkan nilai signifikan dengan sig 0,05 jika nilai sig $<0,05$ maka variabel tersebut berpengaruh secara signifikan. Sehingga uji t sesuai tabel diatas adalah sebagai berikut:

1) Komunikasi $\left(X_{1}\right)$

Hasil uji t untuk variabel Konflik Kerja $\left(X_{1}\right)$ diperoleh nilai signifikan $0,014<\alpha 0,05$ maka Ho ditolak dan Ha diterima yang berarti ada pengaruh signifikan antara Komunikasi terhadap Kinerja Pegawai pada Dinas Perdagangan Provinsi Sumatera Selatan.

2) Lingkungan Kerja $\left(X_{2}\right)$

Hasil uji t untuk variabel Lingkungan Kerja $\left(X_{2}\right)$ diperoleh nilai signifikan $0,006<\alpha$ 0,05 maka Ho ditolak dan Ha diterima yang berarti ada pengaruh signifikan antara Lingkungan Kerja terhadap Kinerja Pegawai pada Dinas Perdagangan Provinsi Sumatera Selatan. 


\section{2) Hasil Uji F (Secara Simultan)}

Uji F digunakan untuk mengetahui pengaruh dari Komunikasi dan Lingkungan Kerja terhadap Kinerja Pegawai secara bersama-sama.

\begin{tabular}{llrrrrr}
\multicolumn{7}{c}{$\begin{array}{c}\text { Tabel Hasil Uji F } \\
\text { ANOVA }\end{array}$} \\
\hline \multirow{2}{*}{ Model } & Sum of & & Mean & & \\
\hline 1 & Regression & Squares & Df & Square & \multicolumn{1}{c}{ F } & Sig. \\
\hline & Residual & 1196,558 & 2 & 598,279 & 21,298 &, $000^{\mathrm{b}}$ \\
& Total & 1853,993 & 66 & 28,091 & & \\
\hline
\end{tabular}

a. Dependent Variable: Kinerja Pegawai

b. Predictors: (Constant), Lingkungan Kerja, Komunikasi

Sumber: Data diolah dengan SPSS versi 22

Dari hasil uji hipotesis uji F diatas diperoleh nilai Fhitung sebesar 21,298 dan nilai signifikan sebesar 0,000. Ini berarti signifikan 0,000<a 0,05. Dari hasil analisis tersebut maka dapat disimpulkan Ho ditolak dan $\mathrm{Ha}$ diterima. Hal ini menunjukkan bahwa ada pengaruh signifikan antara Komunikasi dan Lingkunga Kerja secara bersama-sama terhadap Kinerja Pegawai pada Dinas Perdagangan Provinsi Sumatera Selatan.

\section{E. PEMBAHASAN}

Dari hasil perhitungan uji validitas menjelaskan bahwa seluruh item pernyataan yang digunakan untuk mengukur variabel yang digunakan didalam penelitian ini mempunyai rhitung yang lebih besar dari pada rtabel 0,237. Dari sample sebanyak 69 pegawai. Dari hasil yang didapatkan tersebut didapatkan hasil bahwa semua item peryataan (Indikator) Valid.

Dari hasil uji realibilitas Komunikasi, Lingkungan kerja, dan Kinerja Pegawai masing-masing memperoleh nilai Cronbach'Alpha sebesar 0,732, 0,749, 0,704. Karena semua nilai tersebut $>0,60$, maka dapat disimpulkan bahwa seluruh item pertanyaan reliable.

Berdasarkan hasil regresi linier sederhana antara Komunikasi $\left(X_{1}\right)$ terhadap Kinerja Pegawai $(Y)$ diperoleh nilai koefisien regresi sebesar 0,771 dan nilai konstanta 22,412, sehingga diperoleh persamaan $Y=22,412+0,771$, artinya apabila Komunikasi $\left(X_{1}\right)$ mengalami kenaikan 1 satuan, maka nilai Kinerja Pegawai $(Y)$ mengalami peningkatan senilai 0,771 , selanjutnya hasil regresi linier sederhana antara Lingkungan Kerja $\left(\mathrm{X}_{2}\right)$ terhadap Kinerja Pegawai $(\mathrm{Y})$ diperoleh nilai koefisien regresi sebesar 0,925 dan nilai konstanta sebesar 22,915. Sehingga diperoleh persamaan $Y=22,915+0,925$. Artinya apabila Lingkungan Kerja $\left(X_{2}\right)$ mengalami kenaikan 1 satuan, maka nilai kinerja pegawai $(Y)$ mengalami peningkatan sebesar 0,925 .

Dari hasil regresi linier berganda diperoleh nilai koefisien regresi untuk Komunikasi $\left(X_{1}\right)$ sebesar 0,443 dan nilai koefisien regresi untuk Lingkungan Kerja $\left(X_{2}\right)$ sebesar 0,583 dan nilai konstanta sebesar 16,497. Berdasarkan nilai tersebut diperoleh persamaan regresi linier berganda $Y=16,497+0,0,443 X_{1}+0,583 X_{2}+e$ Artinya apabila Komunikasi $\left(X_{1}\right)$ mengalami kenaikan 1 satuan, maka nilai Kinerja Pegawai $(Y)$ mengalami peningkatan sebesar 0,443 . Selanjutnya apabila Lingkungan Kerja $\left(\mathrm{X}_{2}\right)$ mengalami kenaikan 1 satuan, maka nilai Kinerja Pegawai $(\mathrm{Y})$ mengalami peningkatan sebesar 0,583 . 


\section{Pengaruh Komunikasi Terhadap Kinerja Pegawai Pada Dinas Perdagangan Provinsi Sumatera Selatan.}

Dari hasil pengujian hipotesis (Uji t) secara parsial antara variabel komunikasi $\left(X_{1}\right)$ terhadap variabel Kinerja pegawai $(Y)$ diperoleh nilai signifikan sebesar 0,014 < a 0,05 maka dapat disimpulkan bahwa secara parsial ada pengaruh yang signifikan antara komunikasi terhadap kinerja Pegawai pada Dinas Perdagangan Provinsi Sumatera Selatan.

\section{Pengaruh Lingkungan Kerja Terhadap Kinerja Pegawai Pada Dinas Perdagangan Provinsi Sumatera Selatan.}

Selanjutnya hasil pengujian hipotesis (uji t) secara parsial antara variabel Lingkungan Kerja $\left(\mathrm{X}_{2}\right)$ terhadap variabel Kinerja Pegawai $(\mathrm{Y})$ diperoleh nilai 0,006 < a 0,05 yang signifikan antara Lingkungan Kerja terhadap Kinerja Pegawai pada Dinas Perdagangan Provinsi Sumatera Selatan

\section{Pengaruh Komunikasi dan Lingkungan Kerja Terhadap Kinerja Pegawai Pada Dinas Perdagangan Provinsi Sumatera Selatan.}

Dari hasil pengujian hipotesis (Uji $F$ ) secara bersama-sama antara variabel Komunikasi $\left(\mathrm{X}_{1}\right)$ dan variabel Lingkungan Kerja $\left(\mathrm{X}_{2}\right)$ terhadap Kinerja Pegawai $(\mathrm{Y})$ diperoleh nilai Signifikan sebesar 0,000 < 0,05 maka hipotesis alternative (Ha) diterima dan hipotesis nol (Ho) ditolak. maka dapat disimpulkan bahwa secara bersama-sama ada pengaruh yang signifikan antara Komunikasi dan Lingkungan Kerja terhadap Kinerja Pegawai pada Dinas Perdagangan Provinsi Sumatera Selatan.

\section{F. KESIMPULAN DAN SARAN}

1) Kesimpulan

Berdasarkan analisis data dan penjabaran yang telah dilakukan maka dalam penelitian ini dapat diperoleh kesimpulan sebagai berikut:

a. Dari hasil pengujian hipotesis (Uji t) secara parsial antara Variabel komunikasi $\left(\mathrm{X}_{1}\right)$ terhadap variabel Kinerja pegawai $(\mathrm{Y})$ diperoleh nilai signifikan sebesar $0,014<$ a 0,05 maka dapat disimpulkan bahwa secara parsial ada pengaruh yang signifikan antara komunikasi terhadap kinerja Pegawai pada Dinas Perdagangan Provinsi Sumatera Selatan.

b. Selanjutnya hasil pengujian hipotesis (uji t) secara parsial antara variabel Lingkungan Kerja $\left(\mathrm{X}_{2}\right)$ terhadap variabel Kinerja Pegawai $(\mathrm{Y})$ diperoleh nilai $0,006<\alpha$ 0,05 yang signifikan antara Lingkungan Kerja terhadap Kinerja Pegawai pada Dinas Perdagangan Provinsi Sumatera Selatan.

c. Dari hasil pengujian hipotesis (Uji F) secara bersama-sama antara variabel Komunikasi $\left(\mathrm{X}_{1}\right)$ dan variabel Lingkungan Kerja $\left(\mathrm{X}_{2}\right)$ terhadap Kinerja Pegawai (Y) diperoleh nilai Signifikan sebesar 0,000 < a 0,05 maka hipotesis alternative (Ha) diterima dan hipotesis nol (Ho) ditolak. maka dapat disimpulkan bahwa secara bersama-sama ada pengaruh yang signifikan antara Komunikasi dan Lingkungan Kerja terhadap Kinerja Pegawai pada Dinas Perdagangan Provinsi Sumatera Selatan.

2) Saran

Beberapa saran yang ingin penulis sampaikan kepada pihak Dinas Perdagangan Provinsi Sumatera Selatan adalah sebagai berikut : 
a. Untuk lebih membuat komunikasi kerja yang lebih baik disarankan kepada

Dinas Perdagangan Provinsi Sumatera Sealatan sebaiknya melakukan koordinasi dengan cara komunikasi yang sehat, sikap saling terbuka dan transparan untuk menghindari kesalahpahaman yang mungkin terjadi dan pimpinan hendaknya memahami kondisi yang terjadi serta membentuk komunikasi yang saling mengisi antara pimpinan, pegawai dan sesama rekan kerja.

b. Untuk meningkatkan kualitas lingkungan kerja yang baik, maka penulis menyarankan kepada Dinas Perdagangan Provinsi Sumatera Selatan untuk lebih memperhatikan lingkungan kerja ditempat pegawai bekerja dengan cara selalu memperhatikan sarana dan prasarana untuk bisa meningkatkat kinerja pegawai, instansi haruslah sering memperhatiakan lingkungan sekitar mulai dari internal dan eksternal. Lingkungan kerja yang baik dan nyaman akan membuat pegawai merasa senang dalam bekerja,

c. Untuk meningkatkan kinerja pegawai, maka penulis menyarankan kepada Dinas Perdagangan Provinsi Sumatera Selatan untuk terus memperhatikan perkembangan kinerja pegawai agar dapat menjadi bahan evaluasi terhadap perencanaan yang akan datang untuk meningkatkan kinerja pegawai kearah yang lebih baik lagi.

\section{DAFTAR PUSTAKA}

Busro, Muhammad. 2018. Teori-Teori Manajemen Sumber Daya Manusia. Jakarta : Prenada Media Group.

Kurniawan, Albert. 2014. Metode Riset Untuk Ekonomi dan Bisnis. Bandung: Alfabeta.

Mangkunegara, 2015. Manajemen Sumber Daya Perusahaan. Badan Penerbit PT. Remaja Rosdakarya. Bandung

Oktariansyah, 2012. Pengaruh Kepemimpinan Dan Lingkungan Kerja Fisik Terhadap Motivasi Kerja Karyawan CV. Sedulur Palembang. Jurnal Media Wahana Ekonomika Vol. 9, No.2, Juli 2012 : 80 - 93

Priyatno, Duwi. 2016. Paham Analisa Statistik Data dengan SPSS. Yogyakarta: Mediakom Remaja Rosdakarya.

2018. Buku Panduan Muda Olah Data bagi Mahasiswa dan Umum. Bandung Alfabeta.

Prihantoro, 2015. Peningkatan Kinerja Sumber Daya Manusia Melalui Motivasi, Disiplin, Lingkungan Kerja, dan Komitmen. Yogyakarta : CV Budi Utama

Riduwan, 2015. Belajar Mudah Penelitian Untuk Guru-Karyawan dan Peneliti Pemula. Bandung : Alfabeta. 
Sastrohadiwiryo, Siswanto. (2009). Manajemen Tenaga Kerja Indonesia Pendekatan Administrasi dan Oprasional, Bumi Aksara, Jakarta.

Sedarmayanti, 2011. Tata Kerja dan Produktivitas Kerja : Suatu Tinjauan Dari Aspek Ergonomi Atau Kaitan Antara Manusia dengan Ligkungan Kejranya. Cetakan Ketiga. Bandung : Mandar Maju.

Siregar. 2017. Statistik Parametrik Untuk Penelitian Kuantitatif. Jakarta: Bumi Aksara.

Sugiyono, 2015.Metodelogi Penelitian Kualitatif \& Kuantitatif. Bandung: Alfabeta.

, 2013. Metodelogi Penelitian Bisnis. Bandung: Alfabeta.

Sujarweni, Wiratna. 2015. Metode Penelitian Bisnis dan Ekonomi. Yogyakarta: Pustaka Baru Press.

Sunyoto, Danang. 2015. Penelitian Sumber Daya Manusia. Jakarta : Buku Seru.

Wibowo. 2011. Manajemen Kinerja, Jakarta : Raja Grafindo Persada. 